\title{
Watershed Management in Indonesia: A Regulation, Institution, and Policy Review
}

\author{
Andi Setyo Pambudi ${ }^{1}$ \\ Ministry of National Development Planning/Bappenas - Indonesia
}

\begin{abstract}
Watershed Management as part of regional development in Indonesia is facing various complex and interrelated issues. It is indicated by the lack of integration among sectors, agencies, regions and community participation. The increasing frequency of floods, droughts, landslides, and water crisis problems recently shows that watershed management in Indonesia has not been effective yet in enhancing sustainable development. Furthermore, the damage of watersheds is commonly observed from the upstreams only, such as the addition of cultivated land area and massive settlement, so that erosion and sedimentation affect the declining productivity of land and the increasing frequency of water-related disasters. If watersheds are defined as a container of water cycle, then solving its problem by simply rehabilitating the upstreams is not completely right. Government policies on watersheds management need to be reviewed from its initial aspects of science as well, including existing regulations and institutions, so that the contribution and linkage among sectors could be visible. The concept of Integrated Watersheds Management is basically participatory management of multi-stakeholders in conservations and utilization through an ecological concept of interdependency between nature and human beings. This paper aims to explore the effectiveness of watershed management policies in Indonesia in the context of history, regulation, institutions, and policy implementation.
\end{abstract}

Keywords: Watershed Management, Ecology, Policy, Institutions, Regulation

\footnotetext{
1 Andi Setyo Pambudi is Deputy Director for Monitoring, Evaluating and Controlling Regional Development Area IV, Ministry of National Development Planning/Bappenas RI, e-mail: andi.pambudi@bappenas.go.id
} 


\title{
Watershed Management in Indonesia: A Regulation, Institution, and Policy Review
}

\author{
Andi Setyo Pambudi
}

\section{Introduction}

According to Miller (2015), the main part of environmental studies is ecology, a biological science that links the interaction among organisms and their interaction with the environment. Ecology involves the ecosystem contained its constituent components of abiotic and biotic factors. The environment is defined as an area (region, etc.) or boundary of the economic activity which affects the lives development in it (Common and Stagl, 2005, Bellfield et al., 2016). Watersheds are described as hydrologic units that living quarters or platforms of the environmentalbased economic activities (Common and Stagl, 2005; Miller and Spoolman, 2015, Reddy et al., 2017). The approach applied in the concept of watersheds emphasizes the place-based conservation mechanisms to achieve certain socio-economic and ecological objectives (Dixon, 1992; Abell et al., 2007), including the mechanism that ensures the ecological functions and the biodiversity representation at lowland areas.

The study of Yi et al. (2018) argues that by the continuing decline of biodiversity services and local and global ecosystems, it is important to understand how biodiversity and various ecosystem services interact with each other and how land-use transformation can change the interactions over time. In the context of watersheds, protecting ecosystem is also a way to secure strategic water source areas. The areas can be seen as a pool of shared resources, which may be best controlled through joint management between public and private stakeholders (Carlsson and Berkes, 2005). Unlocking the full potential of strategic water resources area ultimately requires the management of upland areas, as well as the severely affected lowland (downstream) areas (Pittock et al., 2015).

The declining capacity of soil absorption is defined as one of the disrupting factors of the environmental carrying capacity, both in the aspect of upstreamdownstream watershed interaction and sustainability (Bellfield et al., 2015, Euler et al., 2018, Kindu et al., 2018). The low level of formal protection in strategic water resource areas is very concerning that it is very important for water supply. Challenges on the protected water source areas and its impacts indicate the value generated for the community both in its surroundings and environment as a whole (Cumming, 2016; Watson et al., 2014). According to the description, it can be concluded that the term of environmental-based watersheds illustrates a place, a platform, or a hydrological cycle space occupied by living (including human beings) and non-living creatures which are correlated and mutually influenced, either among the creatures themselves or between the creatures and their surroundings, which is not limited by the political or government administrative constraints.

The purpose of watershed management varies across the countries depending on their national priorities In Indonesia, provincial governments are given the opportunity to assist and manage watershed areas that cut across several districts/ municipalities and within districts/ municipalities (Steni, 2016). Furthermore, the management, which generally refers to the actions aimed to achieve sustainability in natural resource management, contributes to the conservation priorities and 
reduces environmental degradation which threatens society's welfare. (Barendse et al., 2016). The watershed illustration in Indonesia is limited by hydrological and unknown administrative boundaries described in Figure 1.

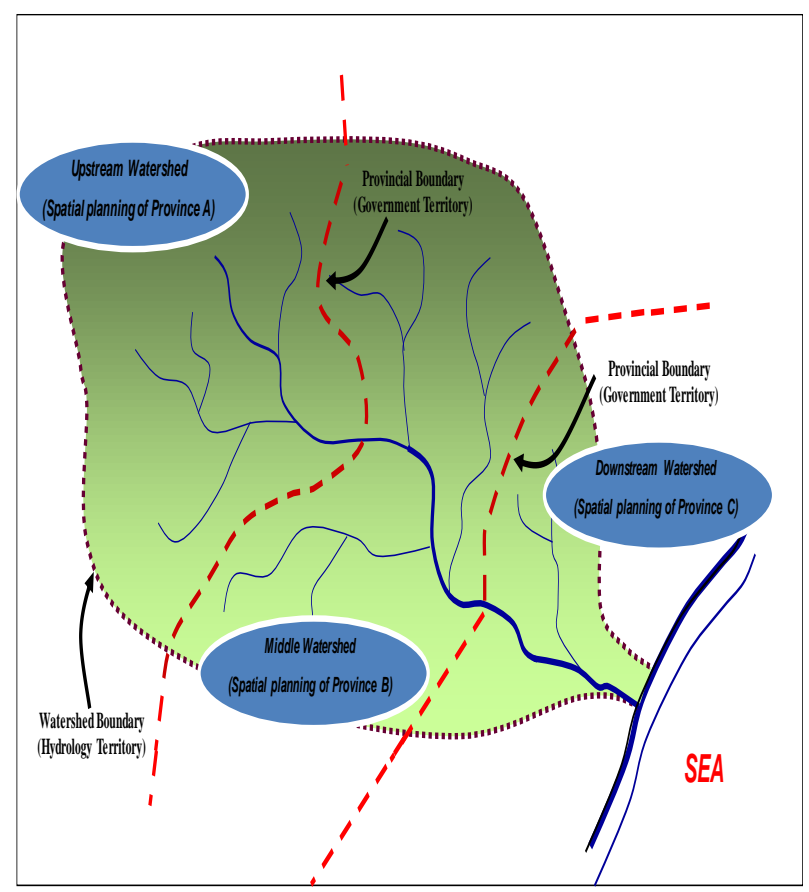

Figure 1. Description of Watershed in Indonesia

Source: Processed from Corn 1993, Swallow et al., 2001, Indonesia Law 23/2014 and Indonesia Government Regulation 37/2012

\subsection{Watershed Management in Indonesia}

In most of the South Asian countries, the evolution of watershed management started early 1980s, though countries like India and Bangladesh had introduced watershed management programs during the 1970s (Reddy, 2017). Watershed Management deals with the changes in the institutional arrangements required for collective action situations (Reddy et al., 2017). It reflects that watershed sustainability is determined by behavior patterns, socio-economic conditions, and management levels which are closely related to the institutional organization (Mtibaa et al., 2018). Many studies have been conducted on the impact of human activity on the regime and capacity arrangement on one environmental factor ( $\mathrm{Li}$ et al., 2018). Watershed management, which is part of regional development in Indonesia, is actually facing various problems such as the absence of integration among sectors, agencies, and regions. Asides from that, community participation has not been optimal yet so that the watershed sustainability is more worrisome. The most visible impact of poor watershed management is illustrated by the condition of water resources in some areas in Indonesia (Bappenas, 2015).

The condition describes above is aligned with the health of watershed. For areas whose health condition is relatively good, the water availability is quite abundant, and vice versa. By the category of islands/group of islands, the forestedland covers located in terrestrial forest area are largely distributed in Papua with a 
width of 32.5 million ha or $33.9 \%$ out of 96 million ha total forested land area in Indonesia, in Kalimantan with the width of 25.6 million ha $(26.7 \%)$, while the smallest area distributed in Bali and Nusa Tenggara with total width of 1.5 million ha $(1.6 \%)$. The other islands have forested-land cover of less than $15.0 \%$ (DG of Forestry and Environmental Planning, 2015)

In terms of terminology, watershed management is a human's attempt to regulate the interrelation between natural resources and human beings along with their activities, in order to realize preservation and the balance of ecosystems along with the increasing utilization of natural resources by humans in a sustainable way (Article 1 paragraph 2 of Indonesian Government Regulation No. 37 Year 2012 on Watershed Management). According to the framework of Watershed Management in Indonesia issued by the Ministry of Forestry Republic of Indonesia in 2009, watershed management fundamentally is a management or optimization of rational land use for various interests and other environmentally friendly practices so that it can be assessed by ultimate indicators of quantity, quality, and continuity of river flow at watershed outlets. If watershed is defined as a container of a water cycle, solving its problem by simply rehabilitating the upstream areas will not be entirely appropriate. Government policies positioning the watershed management no better than forest and land rehabilitation need to be revisited in the context of early science of watersheds itself and its regulatory as well as institutional aspects because it makes the contribution and relevance of other sectors not obvious. Integrated Watershed Management is basically a form of participatory management of multistakeholders in conservation and interdependency utilization of both nature and human beings as part of the ecosystem (Upadani, 2017). On the other hand, in the context of macroeconomic policy, this tendency is increasing in the era of regional autonomy, the management of natural resources at watersheds is orientated to the role of economic development and ignore the environmental insight.

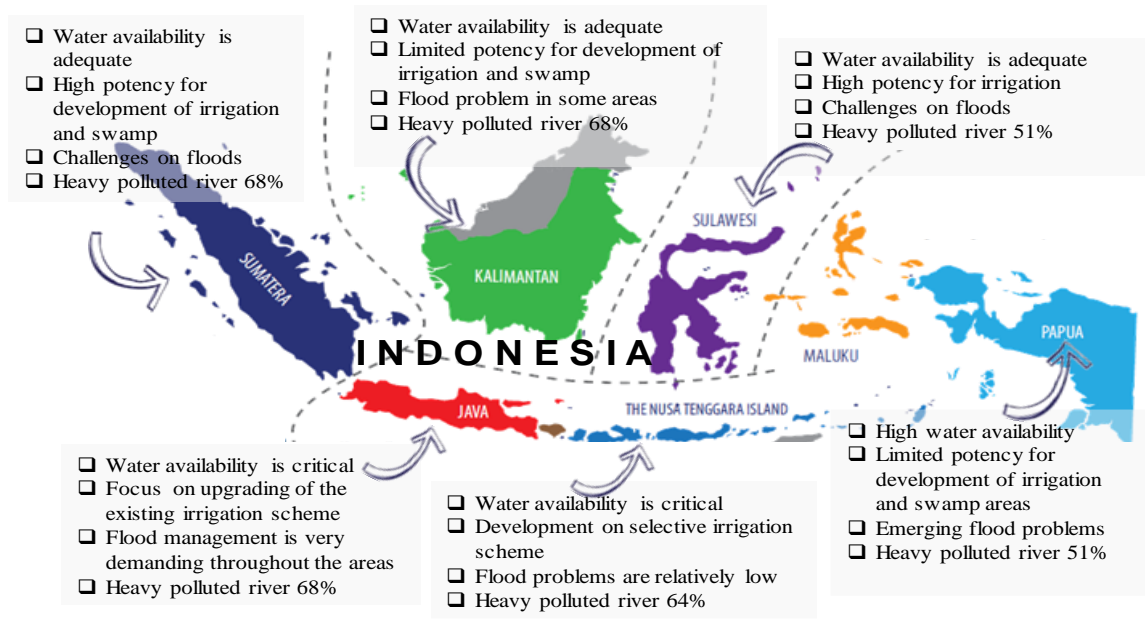

Figure 2. Fact of Water Resources in Indonesia

Source: Bappenas, 2015

Watershed conditions in most parts of Indonesia currently start to decline in terms of quantity and quality. According to Mawardi (2010), the number of critical lands listed still consisted of 22 watersheds in 1984, rising to 39 watersheds in 1990, and reaching 62 watersheds in 1998. Meanwhile, the Indonesian Government stated through the establishment of Minister of Forestry Decree SK.328 / Menhut-II / 
2009 that there were 108 prioritized watersheds out of 17,088 watersheds as a whole in Indonesia that need to be managed immediately.

Integrated Watershed Management is the process of formulating and implementing a course of action involving natural and human resources in a watershed, taking into account social, political, economic and institutional factors operating within the watershed and its surroundings to achieve certain socioeconomic and ecological objectives (Dixon, 1992). Integrated Watershed Management is part of resources management affecting individuals with different interests. Its success is determined by not only the direct executors at field but also other parties who have been involved from the planning phase to the monitoring and evaluation (Ayu and Anna, 2013).

\subsection{Objectives}

The complexity of watershed issues and its management require an effectiveness analysis assessed from various aspects. This paper tries to explore the effectiveness of watershed management policy in Indonesia from the aspects of history, regulation, institutions, as well as policy implementation. The methodology used is desk study by reviewing secondary resources, including the Integrated Watershed Management Plan (RPDAST), River Area Territory Plan, Data of Attaintments, Monitoring and Evaluation of Watersheds by Ministries / Institutions, Spatial Planning Document (RTRW), National Medium Term Development Plan (RPJMN), Regional Medium Term Development Plan (RPJMD), Laws, Ministerial Regulations, Directorate General Regulations, Regional Regulations, Governor / Regent / Mayor Regulations and other documents on the scope of watersheds. As watersheds management is part of managerial, this paper will employ SWOT analysis. In supporting the process of SWOT analysis, qualitative methods are utilized by conducting interviews, discussions, and secondary data tracking.

\section{Evolution of Watershed Management in Indonesia}

Excessive exploitation of natural resources during the Dutch and Japanese colonial era in Indonesia was the main reason behind the rehabilitation in the early independence period at home. In 1946, the Government of Indonesia established a reforestation committee, whose members were from various agencies/departments, to rehabilitate the degraded area of 110,000 ha left by Japan (Mursidin, 1997). However, the committee's plan did not produce any significant results. In 1961, the Ministry of Agriculture and Agrarian Affairs established a committee called the Forest, Land and Water Rescue Committee who was responsible for creating an action plan needed by government to preserve soil fertility, to improve the hydrological cycle at watersheds, and to maintain the sustainability of biodiversity in Indonesia (Ditjen RLPS and Kemenhut, 2003). Nawir et al. (2008) stated that one of the outcomes subtracted from the committee's recommendations is the decision to hold an annual National Reforestation Week which was launched for the first time in 1961. This activity aimed to provide a counseling program that supported campaigns for promoting the importance of forest, land and water conservation. From 1950 to 1970 , rehabilitation activities were generally undertaken through government-led projects including the establishment of the Presidential Instruction on Tree Planting in the 1970s. The main approach of the rehabilitation program focuses on raising public awareness. It aimed to address the negative impacts of inappropriate agricultural activities. Programs that were initiated during the period employed national campaigns and national ceremonies to influence some targeted

The Indonesian Journal of Development Planning

Volume III No. 2 - August 2019 
communities. One of the programs was Karang Kitri, a national campaign that began on October 1951 (1951-1960) with the purpose of encouraging people to plant trees at yards and other lands.

The great flood that occurred in Solo in 1966 was a starting point for Indonesian Government to take rehabilitation more seriously (Ditjen RLPS and Kemenhut, 2003). Soil and water conservation at post-flood disaster in the Bengawan Solo was the main rehabilitation program until the 1970s. The program focused on erosion control at upstream which was mainly caused by deforestation and inappropriate agricultural practices. In the early 1970s, most of the degraded areas were concentrated in Java. Conservation farming on slopes by applying soil and water conservation methods, a combination of vegetative and civil engineering techniques, was a widely used system, especially in Java. The technical civil methods were used extensively and the counseling program was enhanced through the deployment of 5,560 Field Forestry Instructors (Santoso, 1997). In the Fourth FiveYear Plan (Repelita) of the New Order, the management of degraded forest and land was established through a priority scale system. For this purpose, 36 watersheds were selected from 70 districts in 23 provinces. The main activities are the construction of demonstration plots, the construction of dams, the development of community forests, and the making of village seedling. In the fifth Repelita, reforestation and afforestation programs were enhanced through the local community engagement, such as organizing self-help rehabilitation events, enhancing community institutional capacity, and developing human resource capacity especially youth and women (Nawir et al., 2008).

According to Mursidin (1997), based on observations of sedimentation levels at some watersheds in West Java, Central Java, and East Java, the soil erosion rates occurring in the highland areas of Java was quite alarming. In early 1999, rehabilitation programs were still being implemented to continue the reforestation programs in the 1970s. However, the program implemented under this regional autonomy policy had been under intense pressure due to forest encroachment during the upheaval of political reform. The Master Plan for Forest and Land Rehabilitation (MPRHL) was developed in 2000 and was used as a basis to plan the direction of forest and land rehabilitation programs. In 2003, the Ministry of Forestry launched the National Movement for Forest and Land Rehabilitation (GN-RHL / Gerhan) to respond the need for rehabilitation due to the increasingly widespread degradation issues. Meanwhile, Santoso (2005) stated that the GNRHL / Gerhan Program is considered a moral movement that invites the community to participate in forest and land rehabilitation activities. The total target area is 3,000,000 ha with a total budget of Rp. 5.9 trillion ( \pm US $\$ 670.6$ million). This will be achieved gradually with 300,000 ha in 2003, 500,000 ha in 2004, 600,000 ha in 2005, 700,000 ha in 2006 and 900,000 ha in 2007. The target area is located in 236 districts which consist of 68 prioritized watersheds in 27 provinces. Priority areas are critical watersheds with degradation level of forestry and critical lands, which are vulnerable to natural disasters and consists of small forest cover area (General Directorate RLPS, Ministry of Forestry, 2003). In 2003, GNRHL / Gerhan was implemented in 15 provinces covering 26 watersheds, while in 2004 it was implemented in 31 provinces covering 141 watersheds and 374 districts/cities (Santoso, 2005).

The use of watershed as a natural resource management planning unit was established in 1988 which is part of the national development strategy. It shows that the role of watersheds turns out a part of the government's concern (Baplan Kemenhut, 2003). Watersheds are also the main unit of management approach 
which was used in the Master Plan for Forest and Land Rehabilitation in 2000. As the approach of watersheds is more holistic, it can be used to evaluate the relationship between biophysical factors and the intensity of socio-economic activities as well as culture from upstream to downstream areas. Asides from that, it can be used to assess the environmental impact more quickly and easily. The Mandate of Government Regulation No. 44/2004 on Forestry Planning, particularly in Article 1 Paragraph 1, explains that forestry planning is the process of goal setting as well as the arrangement of activities and necessary tools for sustainable forest management by providing guidance and direction to ensure the achievement of forest management objectives, which are the greatest, fair, and sustainable prosperity of human being. Meanwhile, Article 32 Paragraph 2 of the Government Regulation stated that every forest management unit must be based on the characteristics of the Watershed (DAS) concerned. In 2012, the Government Regulation (PP) Number 37 Year 2012 on Watershed Management was issued. Given this regulation, policy of watersheds and its management becomes clearer.

In the previous two periods of the Indonesian National Medium-Term Development Plan (RPJMN), which are the RPJMN 2004-2009 and RPJMN 20102014, the management of watersheds has not yet been clear even though some activities were leading to it. The new watershed management was clearly stated in the water security section of RPJMN 2015-2019. Fundamentally, water resilience covers 2 (two) things: 1) water adequacy, quantity, quality, and sustainability including the sustainability of life and ecosystem, and 2) ability to reduce water damage risk.

In the National Medium Term Development Planning (RPJMN Indonesia) period of 2015-2019, watershed management is written on environment section that it is a part of responsibility of several ministries, including Ministry of Environment and Forestry, Ministry of Public Works, Ministry of Agriculture, and Ministry of Energy and Mineral Resources, BMKG and so forth. In order to support watershed management in regions, there have been 15 local regulations, namely 13 Provincial Watershed Management Regulations and 2 District / Municipal Watershed Regulations.

\section{Watershed Institutional Structure}

In a study conducted by Bappenas (2015), the concept of water security should not only be analyzed from the aspects of surface water and blue water, but also green water. This shifting perspective had transformed management approach applied to the institutional-governance which emphasizes synergies among institutions whose responsible were conserving land and water (Protected Forest and Watershed Management Office/BPDAS-HL), controlling the conservation of surface water (River Area Territory Office/ BWS), and managing the groundwater (Groundwater Office). The synergy and coordination approach became an important point due to the lack of institutional innovation responding to the water resistance issue. Sectoral ego was still a major obstacle in implementing effective coordination between two institutions that conserved green water and managed the blue water conservation. Both of their responsibilities had been built upon their own rules. In addition, watershed units that were supposed to have no cross-border provincial /district/city administrations and even across countries administration had changed their management patterns following decentralization policies hence the concept of the watershed faced serious coordination problems. 
Helen et al. (2016) stated that the Indonesian government organization is complex and growing where up to now there are about 34 ministries, 4 ministrylevel government agencies, 29 non-ministerial institutions, 34 provinces, and more than 500 districts and municipalities. Since the reforms that began in the 1990 s, government authorities have been increasingly delegated to provinces/districts and away from the central government in Jakarta. This delegation is strengthened by the issuance of Law Number 23 Year 2014 on Regional Government. This further underscores the central power of the central government to dictate policies, horizontally (between Ministries / Agencies), as well as vertically (between central, provincial and district governments).

The results of research conducted by Mairi et al. (2014) show that the most appropriate form of the institution to be applied in integrated watershed management was a combination of Polycentric and Monocentric. It required a collaborative work such as DAS/LK-PDAS forum (Institution of Watershed Management Coordination) at Provincial level whose members are the head of each agency in the region/ OPD/ Sectoral Organization of Local Officials. This institution was non-structural and directly responsible to the Governor as the policy authority. The DAS / LK-PDAS Forum served as a forum for communication, consultation and coordination among stakeholders in order to help the Governor formulating a watershed management policy across the districts. In 2013, the forum came into force as part of the government-recognized watershed management by the issuance of Minister of Forestry Regulation Permenhut P.61 / Menhut-II/ 2013 on the Watershed Management Coordination Forum. In the Renstra Document of Directorate General of Watershed Control and Protected Forest KLHK 2015-2019, 1 national-level Watershed Management Coordination Forum, 3 inter-provincial Watersheds Forum, 40 watershed forums with governor's approval, 51 Watersheds Forum with regents/mayors approval, and 14 watersheds forum with initiation of Non-Governmental Organizations / NGOs have been created. Nevertheless, considering the watershed-related budgeting is still dominated by the state budget, the role of BPDAS-HL and BWS is very important to realize the implementation of watershed management. The synergy of institutions, regulation and policy is the key implementation supported by input generated from watersheds forum which its capacity as a "think tank" is very important for more independent watershed management.

\section{Policy Review: SWOT Analysis}

The management of water resources can not be separated from the watersheds management unit as they are part of hydrological cycle. Watersheds, a component of water resources landscape, has been damaged followed by the degradation of environmental quality. Indicators which can be addressed as a result of watershed destruction in Indonesia include (1) an increasing rate of erosion and sedimentation due to the land use transformation from forestry to agriculture, plantations, and settlements at upstreams; (2) the conspicuous fluctuation of river flow in the rainy season and dry season, and (3) the declining quality and quantity of surface water and groundwater. Various interventions have been undertaken to manage the damages, such as policy instruments, budget allocation, and institutional innovations, however, they do not exhibit any optimum results as what is expected. Problems of erosion, sedimentation, drought, and floods continue to occur as a result of damaged watersheds. In accordance with RPJMN 2015-2019 issued by the government, several problems related to water resources management turn out the government's focus and attention to be solved, including: (1) the lack of 
availability of irrigation water and reservoir in the dry season; (2) the utilization of water has not been well managed yet; (3) the unfinished recovery of the national priority watersheds quality; (4) the critical land area inside and outside the forest is still high followed by the high rate of deforestation.

\subsection{Assessment of strengths, weaknesses, opportunities, and threats}

SWOT analysis is used to map internal and external factors affecting the managerial. On the internal factors, the exploration of strengths and weaknesses on watersheds management scope is important in order to see how far they support watersheds management in Indonesia. External factors contained opportunities and threats are mapped in order to see how much opportunity is available and how far the threat will affect watersheds management. Based on the results obtained from the interviews, discussions, and tracing of available secondary data, the results of assessments of strengths, weaknesses, opportunities, and threats of watershed management in Indonesia are presented in Table 1.

Table 1. Assessment of Strengths, Weaknesses, Opportunities, and Threats of Watershed Management in Indonesia

\begin{tabular}{|c|c|}
\hline Strength & Weakness \\
\hline 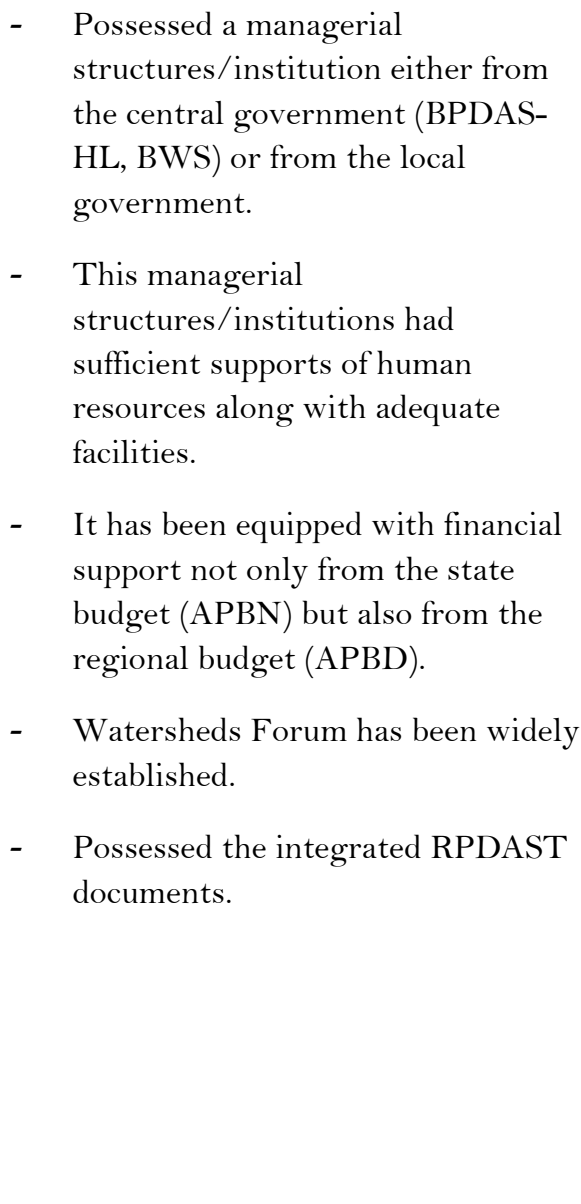 & $\begin{array}{l}\text { The weak coordination between } \\
\text { central agencies (BPDAS-HL, } \\
\text { BWS) and local agencies } \\
\text { (Bappeda, OPD / Organization } \\
\text { of the related Regional Regions). } \\
\text { - The sectoral ego is still attached } \\
\text { to each agency indicated by } \\
\text { perceptions of local government } \\
\text { agencies who assume that the } \\
\text { RPDAST is a sole responsibility } \\
\text { of BPDAS-HL. } \\
\text { The integrated RPDAST } \\
\text { documents have not been } \\
\text { internalized in RTRW / } \\
\text { RPJMD } \\
\text { Funding of Watersheds Forum } \\
\text { mostly depends on the state } \\
\text { budget of the Ministry of } \\
\text { Environment and Forestry. } \\
\text { RTRW has not been utilized for } \\
\text { land use and spatial planning } \\
\text { Observation stations of river } \\
\text { water are not yet equally } \\
\text { distributed and some can not be }\end{array}$ \\
\hline
\end{tabular}

The Indonesian Journal of Development Planning

Volume III No. 2 - August 2019 


\begin{tabular}{|c|c|}
\hline Strength & Weakness \\
\hline & $\begin{array}{l}\text { utilized properly so that data of } \\
\text { watersheds evaluation are unable } \\
\text { to be analyzed to support the } \\
\text { management. }\end{array}$ \\
\hline Opportunity & Threat \\
\hline 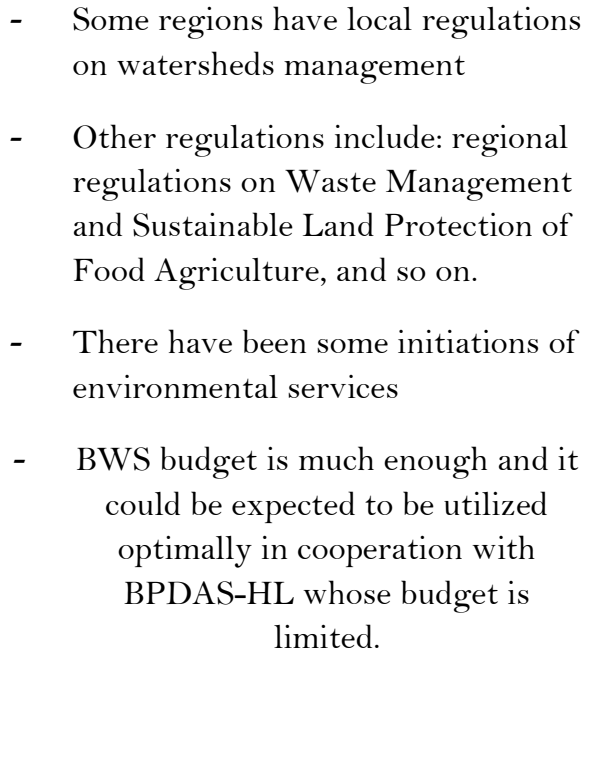 & $\begin{array}{l}\text { - } \begin{array}{l}\text { The continuity of forest } \\
\text { degradation, land-use change in } \\
\text { watersheds }\end{array} \\
\text { - } \quad \begin{array}{l}\text { Erosion and sedimentation } \\
\text { continue to occur. }\end{array} \\
\text { - } \quad \begin{array}{l}\text { Illegal logging, forest } \\
\text { encroachment, cultivation of } \\
\text { forest land for agriculture in } \\
\text { conservations, protected and } \\
\text { production forest areas. }\end{array} \\
\text { - Agricultural cultivation practices } \\
\text { which are not environmentally } \\
\text { friendly } \\
\text { Higher population growth and } \\
\text { settlement development. }\end{array}$ \\
\hline
\end{tabular}

Source: Analysis Result, 2019

\subsection{Strategy Approach}

Results from SWOT mapping are used as references to design approaches for management/strategy. As mentioned earlier, the management/strategy is performed through 4 actions based on the interaction between internal and external factors (SO, ST, WO, and WT). The management/strategy for improving watershed management in Indonesia is summarized in Table 2. 
Table 2. Inter-Factor Interaction Mapping for Watershed Management Strategy in Indonesia.

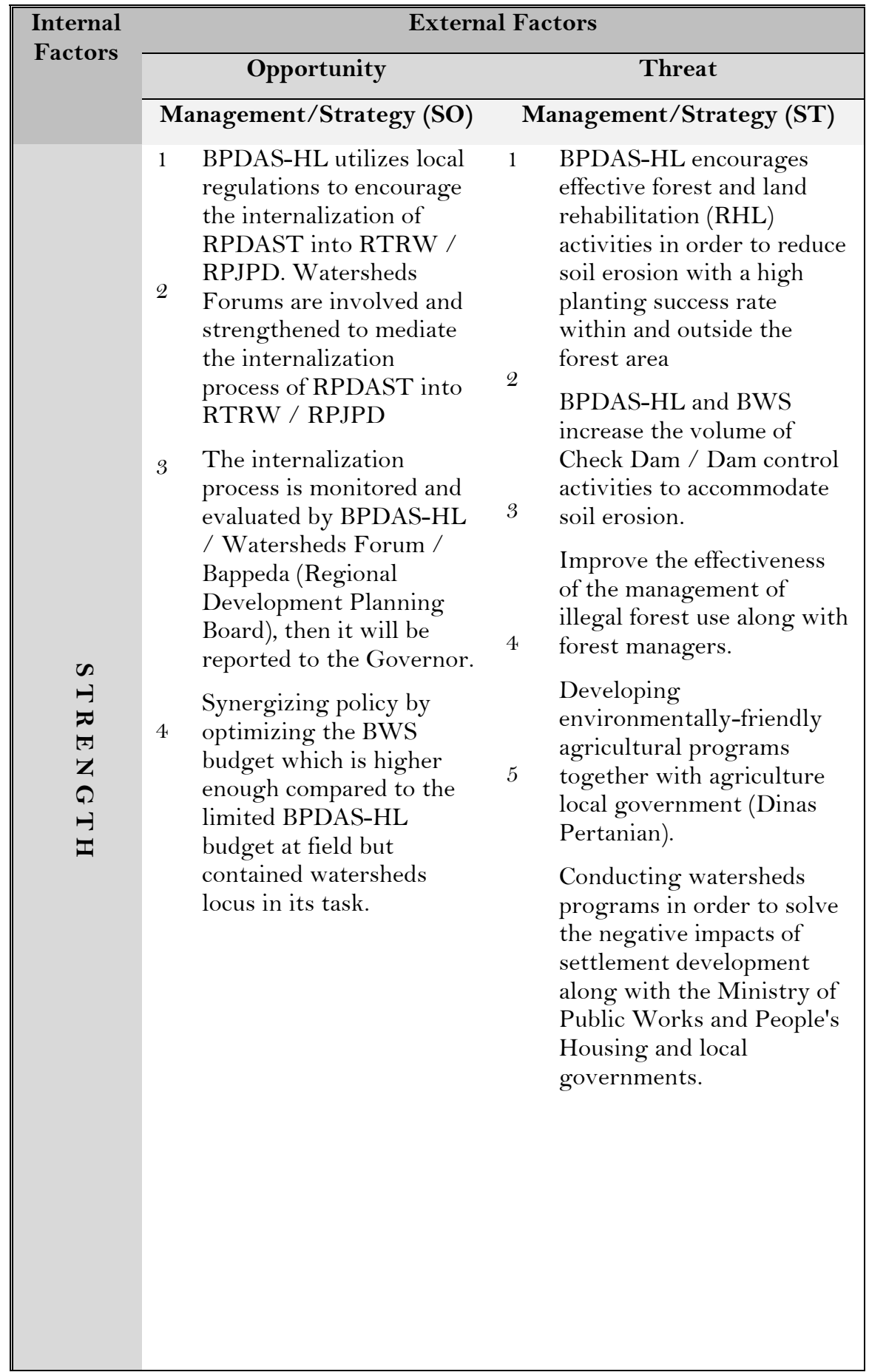




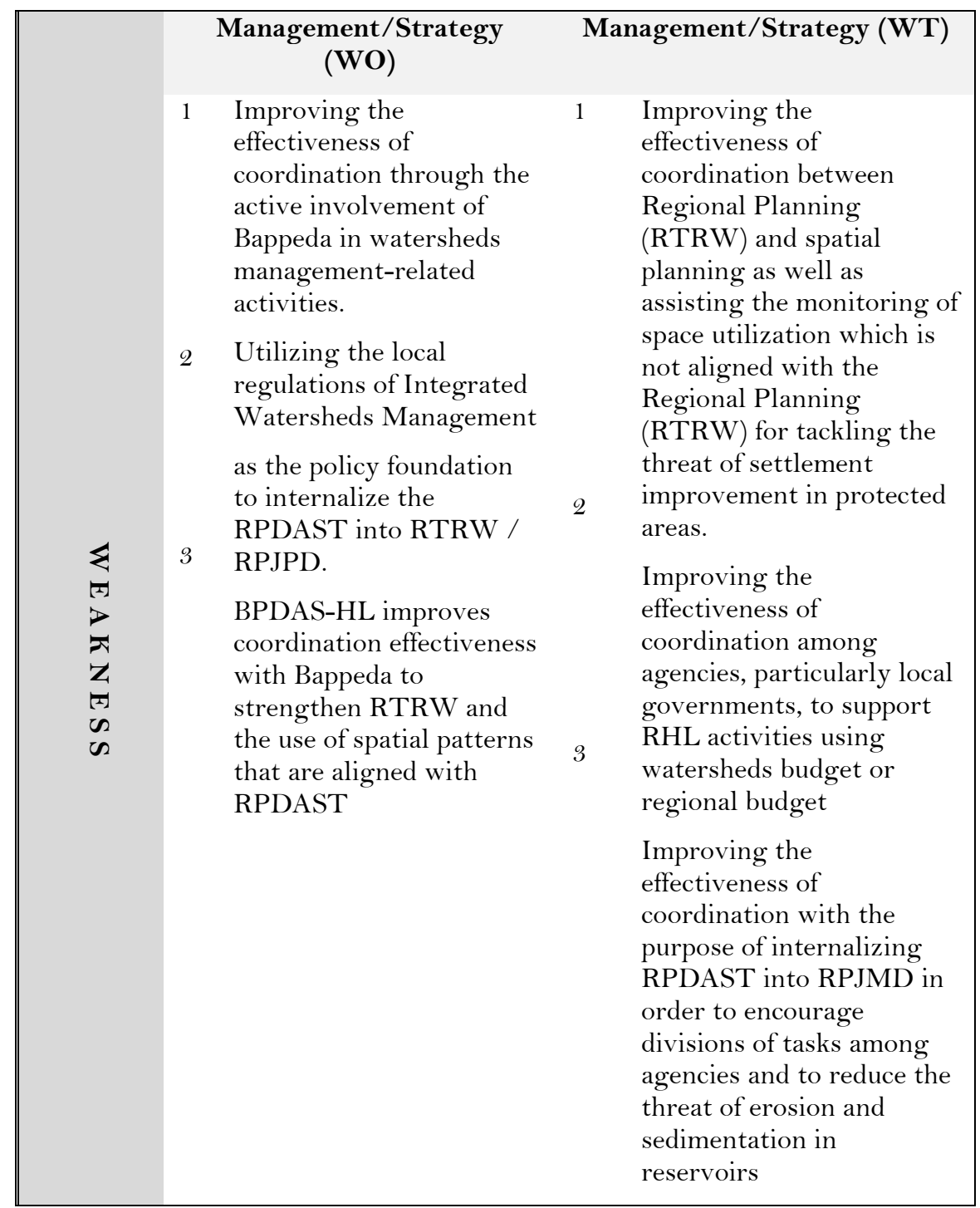

Source: Analysis Result, 2019

\section{Review of Regulation Implementation}

Some regulations, whether Laws, Government Regulations, or Technical Regulations of Ministry, have not yet been effectively implemented to support water management and conservation of water resources. They are Law No.41/1999 on Forestry, Law No.37/2014 on Water Conservation and Land Conservation, Law No. 26/2007 on Spatial Planning, Law No. 18/2003 on Prevention and Eradication of Forest Destruction, Government Regulation No. 26/2008 on National Spatial Planning, Minister of Forestry Regulation P.39/Menhut-II/2009 on Guideline for the creation of RPDAST Establishment, and Regulation of the Ministry of Forestry P.61/Menhut-II/2013 on Coordination Forum of Watersheds Management.

In fact, watersheds management at field still utilizes the old rules for planning, organizing, and monitoring and evaluation. In Indonesia, RPDAST 
generally is still conducted based on Government Regulation No.39/2007 and Regulation of the Ministry of Forestry No P.39/Menhut-II/2009 on the Guideline of the Integrated Watersheds Management Plan Establishment. (RPDAST). It is understandable, that RPDAST of several watersheds was prepared before the establishment of Government Regulation No. 37/2012 on Watersheds Management. In the end, it is important to re-draft or revises RPDAST in accordance with Government Regulation No.37/2012 that the authority of RPDAST drafting is made based on its boundary. However, supportive conditions to achieve the conditions are not yet available. On the obstacles of detailed authority, budget allocation of RPDAST drafting need to be eliminated by issuing derivative regulations from technical ministers (the Ministry of Home Affairs and the Ministry of Environment and Forestry) and by preparing the local government to carry out drafting plans, organizing watersheds management, and monitoring and evaluation which were ruled by the Government Regulation No. 37/2012. If the implementation of watersheds management is in line with the Government Regulation No. 7/2012, the problem of internalization and operationalization of RPDAST at local government are not expected to occur.

\subsection{Conclusions}

The implementation model of watersheds management policy is a policy creation model that was outlined in action plan. The action plan of policy implementation is an important concern in this study because the finding shows the implementation of watersheds-based conservation of water resource which was written on the action plan of RPDAST was ineffective. The performance of action plan generally has not yet been optimal due to the lack of local government's role. So far, action plan produced (RPDAST/Pola PSDA-WS) is still perceived as the responsibility of central government. Asides from that, watersheds management at field still uses the old rules for planning, organizing, and monitoring and evaluation. Furthermore, in Indonesia, RPDAST still refers to the Government Regulation No.38/2007 and Regulation of the Ministry of Forestry No. P.39/Menhut-II/2009 on the Guidelines of Integrated Watersheds Management Plan and has not yet adjusted to the Government Regulation No.37/ 2012. It is understandable because RPDAST of several watersheds was prepared before the establishment of the Government Regulation No. 37/2012 and Law No. 23/2014 on Regional Government. In-Law No.23/2014, the authority of watersheds management across countries and provinces was conducted by the central government, while the watersheds management across districts and cities was conducted by the provincial government. Based on Law No.23/2014, drafting action plan in accordance with Government Regulation No. 37/2012 is undertaken by the provincial government, particularly watersheds which are located across districts and cities. Therefore, it is necessary to develop RPDAST as mandated by Government Regulation No.37/2012 and Law No. 23/2014 which explains that the authority of RPDAST drafting is made by the boundaries of watersheds administration area.

Some of the obstacles that need to be solved are mainly related to the detail of authority and budget allocation of RPDAST drafting. They can be eliminated by issuing derivatives regulations of technical ministries (Ministry of Home Affairs and Ministry of Environment and Forestry) and by preparing local governments to carry out drafting plans, organizing watershed management, and monitoring and evaluation in accordance with the administration boundaries of watersheds management ruled by the Government Regulation No.37/2012 and Law No. 23/2014. If watersheds management is in line with Government Regulation No. 
$37 / 2012$, the internalization and operationalization of RPDAST at local government level will be run better and will be aligned with the concept of Law No.23/2014 on Regional Government. Two models below show the process of watersheds-based policy implementation which was outlined through preparation process of action plan adapted to the institutional function of central government and local government (see figures 3 and 4 ).

The model of action plan arrangement is adjusted to the mandate of Government Regulation No. 37/2012 and it is a prerequisite function of watersheds management across sectors and regions. Currently, the process of implementing a watershed-based policy with a vegetative approach is concentrated solely on the central government (BPDAS-HL) as the sole actor who drafts and implement the action plans. Although some RPDAST documents are legalized or obtain legal standing from the local governments, however, the process of action plan-making and budget allocation are fully authorized by the central government (BPDAS-HL). If the mandate of the Government Regulation No.37/2012 is completely implemented, it is necessary to rearrange the organization and its function by providing supports strengthening the local government who has the authority to create action plans (RPDAST) as mandated by the Government Regulation No.37/2012 and Law No.23/2014. The author suggests 4 central ministries/institutions be included in the recommendation schemes, namely the Ministry of National Development Planning/ Bappenas, the Ministry of Environment and Forestry, the Ministry of Public Works and Housing, and the Ministry of Home Affairs.

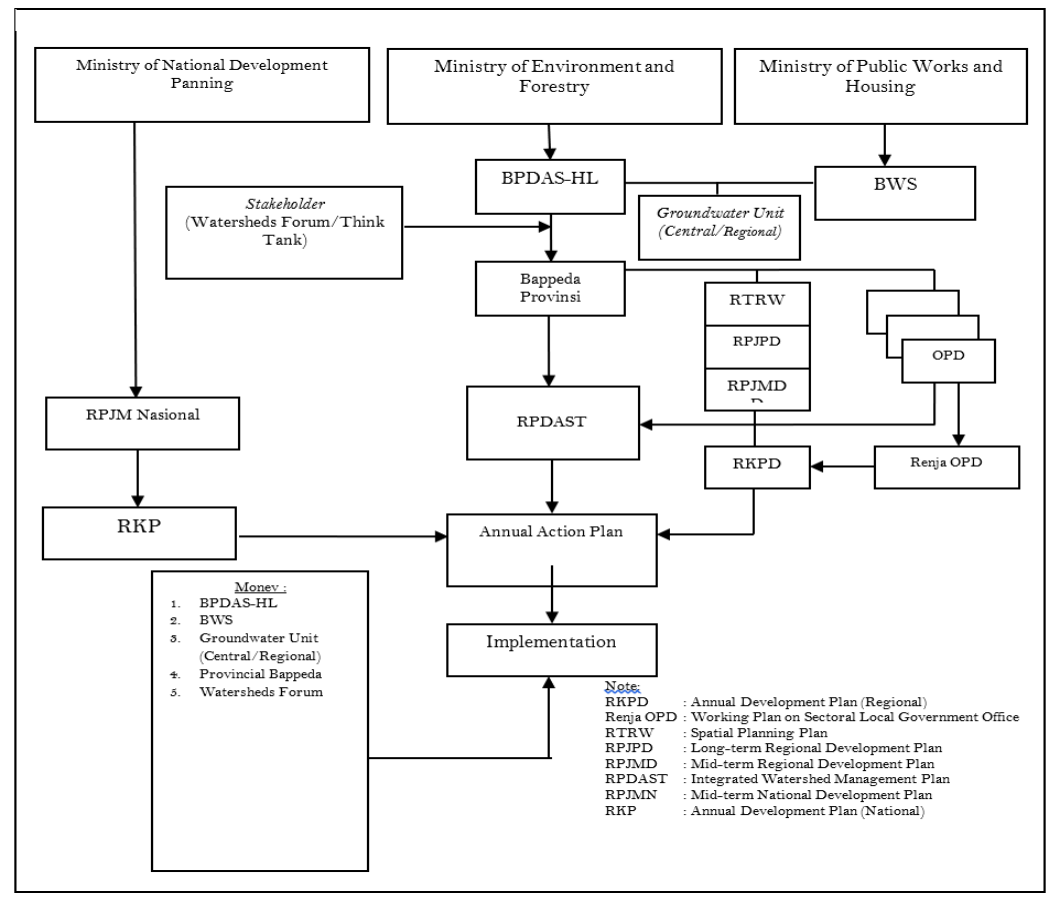

Figure 3. Implementation Model of Watershed Management Policy in accordance with the Government Regulation No. 37/2012 and Law No.

23/2014 on watersheds across countries and provinces in Indonesia

Source: Analysis Result, 2019 


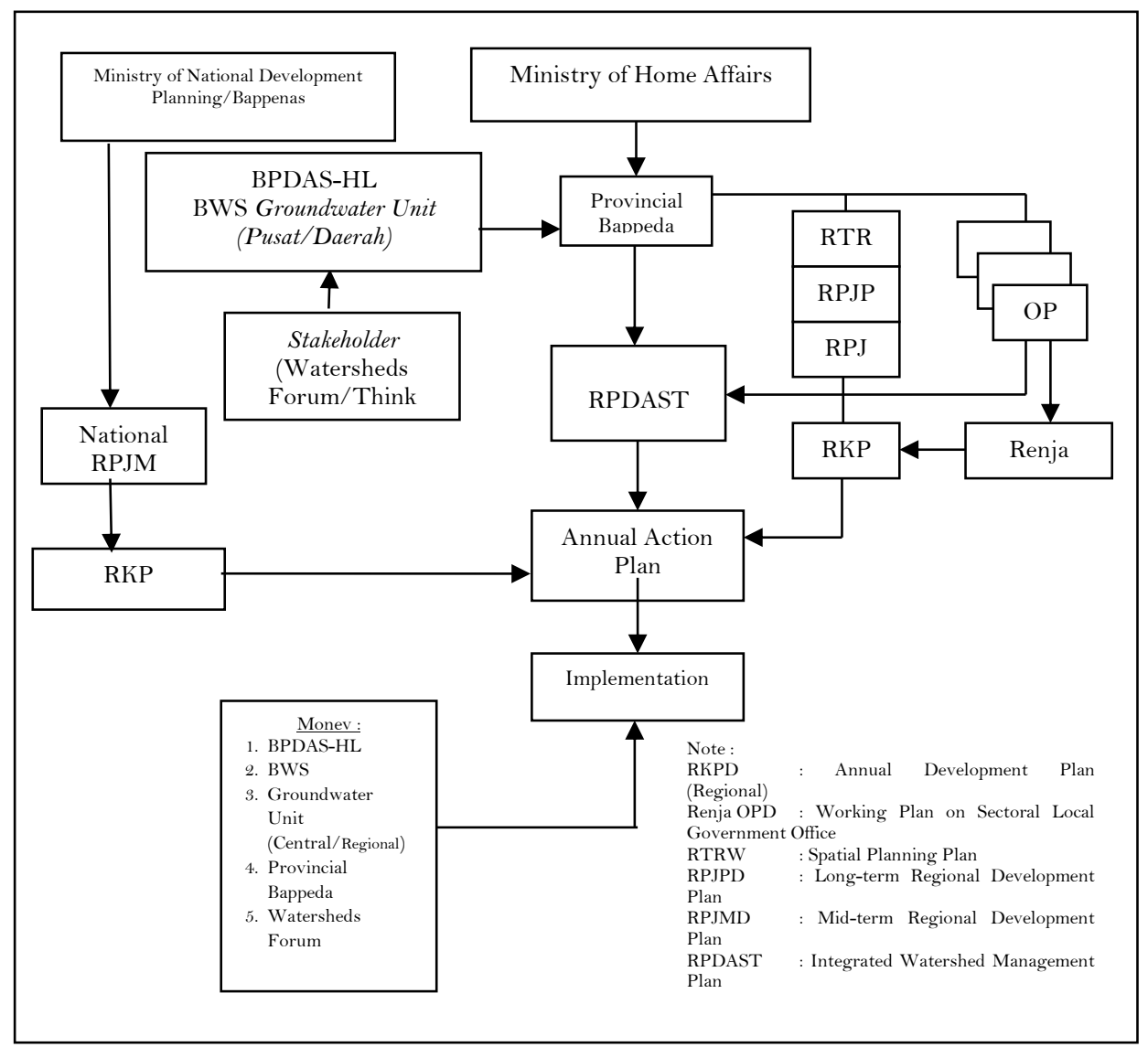

Figure 4. Implementation Model of Watershed Management Policy in accordance with the Government Regulation No. 37/2012 and Law No. 23/2014 on watersheds within provinces in Indonesia

Source: Analysis Result, 2019

On the policy instrument of watersheds management, the results of this study provide recommendations for the development of four regulations (two of them are formal letters issued by ministries). The first one is the Regulation of the Ministry of Foreign Affairs on the Guidelines for the formulation of Watersheds Management Plans at Provincial Government. It aims to complement the Regulation of Ministry of Forestry P.39 / 2009 which is not aligned with the Government Regulation No.37/2012 and to provide guidance for Bappeda / OPD of provincial government for developing the watersheds management plans. The second one is the Government Regulation on the establishment of monitoring and evaluation team of watersheds management plan. It aims to tie up cross-sector cross-regional institutional teams in performing monitoring and evaluation of RPDAST so that monitoring and evaluation could be run optimally as it has been mandated in regulations. Thirdly, the letter issued by Ministry of Environment and Forestry on RPDAST documents drafting across provinces on a self-managed basis. This letter aims to bind the implementation of RPDAST documents drafting independently as it relates to the main tasks and core function of BPDAS-HL organizations. Asides from that, this letter ensures the process of drafting done participate along with the 
local government and water-based Technical Implementation Unit (UPT) directed by the central government.

\section{Reference}

Abell, R., Allan, J.D., Lehner, B. (2007); Unlocking the potential of protected areas for freshwaters. Biol. Conserv. 134, 48-63.

Atapattu, S.S.and Kodituwakku, C.D. (2009); Agriculture in South Asia and its implications on downstream helath and sustainibility: AgricultureWater Management. 96: 361---373

Ayu, I Gusti and Lintje Anna. (2013); Conservation area of Upstream Solo Watershed in order to Sustainable Development. Journal Bestuur. February - May 2013 Edition.

Barendse, J., Roux, D., Currie, B., Wilson, N., Fabricius, C. (2016); A broader view of stewardship to achieve conservation and sustainability goals in South Africa: review article. S. Afr. J. Sci. 112, 21-35.

Carlsson, L., Berkes, F. (2005); Co-management: concepts and methodological implications. J. Environ. Manage. 75, 65-76.

Common, Michael and Sigrid Stagl (2005); Ecological Economic: An Introduction. Cambridge University Press, New York.

Corn, M. L.(1993); Ecosystems, Biomass, and Watersheds: Definitions and Use. Washington, DC.: National Council for Science and the Environment

Cumming, G.S. (2016); The relevance and resilience of protected areas in the Anthropocene. Anthropocene 13, 46-56.

Directorate General of Forestry Planning and Environmental (2015); Book of Indonesia Land Cover Recalculation (Buku Rekalkulasi Penutupan Lahan Indonesia Tahun 2014), Jakarta

Directorate General of Forest Rehabilitation and Social Forestry (2003); Rehabilitasi Lahan dan Perhutanan Sosial: Dari Masa Ke Masa (Forest Rehabilitation and Social Forestry: Inter Time). Ministry of Forestry Indonesia

Dixon J.A. (1992); Analysis and Management of Watersheds, in Partha Dasgupta and Karl-Goran Maler (ed) The Environment and Emerging Development Issues, Vol.2, ClarendonPress, Oxford.

Euler, Johannes, and Sonja Heldt (2018); "Science of the Total Environment From Information to Participation and Self-Organization: Visions for European River Basin Management." Science of the Total Environment 621: 905-14. https://doi.org/10.1016/j.scitotenv.2017.11.072.

Government of Indonesia (2009); Minister of Forestry Decree (Keputusan Menteri Kehutanan) SK.328/Menhut-II/2009 about Priority Watershed on Mid-Term Development Plan (RPJMN) $2010-2014$.

Government of Indonesia (2012); Government Regulation (Peraturan Pemerintah) Number 37 Year 2012 about Watershed Management.

Government of Indonesia (2014); Presidential Regulation (Peraturan Presiden) Number 2 Year 2015) about Mid-Term Development Plan (RPJMN) 2015 - 2019.

Government of Indonesia (2014);. Law (Undang-undang) Number 23 Year 2014 about Local Government

Government of Indonesia (2014); Law Undang-undang) Number 37 Year 2014 about Soil and Water Conservation

Government of Indonesia (2015); Regulation of Directorate General of Watershed Management and Protected Forest (Peraturan Direktur Jenderal Pengendalian Daerah Aliran Sungai dan Hutan Lindung Nomor : P. 10 /PDASHL- 
Set/2015) about Strategic Plan of Directorate General of Watershed Management and Protected Forest Year 2015-2019. Jakarta

Helen Bellfield, Matt Leggett, Mandar, Trivedi, Jeni Pareira, Adi Gangga (2016); How Can Indonesia Achieve Water, Energy and Food Security? WCS and Global Canopy Programme. Indonesia

Hoonchong Yi, Burak Güneralp, Urs P. Kreuter, Inci Güneralp, Anthony M. Filippi et al. (2018); Spatial and temporal changes in biodiversity and ecosystem services in the San Antonio River Basin, Texas, from 1984 to 2010. Journal Science of the Total Environment 619-620 (2018) 1259-1271. Publisher : Elsevier

Kindu, Mengistie et al. (2018); "Science of the Total Environment Scenario Modelling of Land Use / Land Cover Changes in Munessa-Shashemene Landscape of the Ethiopian Highlands." Science of the Total Environment 622-623: 534-46. https://doi.org/10.1016/j.scitotenv.2017.11.338

Kristian Mairi, Iwanuddin, et al. (2014); Institutional Development Strategy for interdistrict Watershed Management (Strategi Pengembangan Kelembagaan Pengelolaan DAS Lintas Kabupaten). Presented to Seminar on Rehabilitation and Restoration of Forest Areas Facing 50 Years of North Sulawesi, organized by the Forestry Research Institute of Manado, Manado October 9, 2014

Lal, R. (2004); The potential of carbon sequestration in soils of South Asia. $13^{\text {th }}$ International Soil Conservation Organization Conference, Brisbane.

Mawardi (2010); Damage to the Watershed and the Decreased Carrying Capacity of Water Resources in Java and its Handling Efforts (Kerusakan Daerah Aliran Sungai dan Penurunan Daya Dukung Sumberdaya Air di Pulau Jawa serta Upaya Penanganannya). Journal of Hidrosfir Indonesia. Jakarta.

Miller, G.T. and S.E. Spoolman. (2015); Living in the Environment: Concepts, Connections and Solutions. Seventeenth edition. Brooks/Cole, Belmont, CA (USA

Mtibaa, Slim, Norifumi Hotta, and Mitsuteru Irie (2018); "Science of the Total Environment Analysis of the Ef Fi Cacy and Cost-Effectiveness of Best Management Practices for Controlling Sediment Yield: A Case Study of the Joumine Watershed, Tunisia." Science of the Total Environment 616-617: 1-16. https://doi.org/10.1016/j.scitotenv.2017.10.290.

Mursidin et al. (1997). 35 years Greening in Indonesia (35 tahun Penghijauan di Indonesia). Presidium of the Natural Resources Conservation Group. Directorate General of Reforestation and Land Rehabilitation of the Ministry of Forestry, Directorate General of Regional Development of the Ministry of Home Affairs. Jakarta.

Nawir, et al. 2008. Forest rehabilitation in Indonesia: Where will it be after more than three decades? (Rehabilitasi hutan di Indonesia: Akan kemanakah arahnya setelah lebih dari tiga dasawarsa?).Bogor, Indonesia: Center for International Forestry Research (CIFOR), ISBN 978-979-14-1235-3.

Reddy, Ratna V., Saharawat, Y.S., George, B. (2017); Watershed Management in South Asia: A Synoptic Review, Journal of Hydrology (2017), doi: http://dx.doi.org/10.1016/j.jhydrol.2017.05.043

Ruonan Li, Hua Zheng, Sunyun Lv, Wenting Liao, Fei Lu et al. (2018); Development and evaluation of a new index to assess hydrologic regulating service at subwatershed scale. Jurnal Ecological Indicators 86 (2018) 9-17. Publisher: Elsevier.

Steni, Bernadius (2016); Review of the New Local Government Law. INOBU (http://inobu.org)

The Indonesian Journal of Development Planning

Volume III No. 2 - August 2019 
Swallow, M. B., N. L. Johnson and R. S. Meinzen-Dick (2001); Working with People for Watershed Management. Water Policy, 3:449-455.

Upadani, I.G.A.W. (2017); Models of Social Capital Utilization in order to Rural Community Empowerment Managing Watersheds (DAS) In Bali (Model Pemanfaatan Modal Sosial Dalam Pemberdayaan Masyarakat Pedesaan Mengelola Daerah Aliran Sungai (DAS) di Bali). Journal of Environment \& Development, June 2017 ISSN 2597-7555 Vol. 1 No. 1: 11-22

Pittock, J., Finlayson, M., Arthington, A.H., Roux, D., Matthews, J.H., Biggs, H., Harrison, I., Blom, E., Flitcroft, R., Froend, R., et al. (2015); Managing freshwater, river, wetland and estuarine protected areas. In: Worboys, G.L., Lockwood, M., Kothari, A., Feary, S., Pulsford, I. (Eds.), Protected Area Governance and Management. ANU Press, Canberra, pp. 569-608.

Santoso, 2005. Policy Direction and Implementation of Forest and Land Rehabilitation. Presentation on "Review of Rehabilitation Initiative Workshop: Lessons from the Past". CIFOR. Bogor.

Santoso, 1992. Implementation (Inpres) Reforestation and Reforestation: Pelita IIIV Progress and Prospect Pelita V-VI. (Pelaksanaan (Inpres) Penghijauan dan Reboisasi : Progres Pelita II-IV dan Prospek Pelita V-VI). Directorate of Soil Conservation Directorate General of RRL. Ministry of Forestry. Jakarta

Watson, J.E., Dudley, N., Segan, D.B., Hockings, M., 2014. The performance and potential of protected areas. Nature 515, 67-7 